\title{
INTEGRATION OF COCONUT PRODUCTION IN WEST KALIMANTAN
}

\author{
Maswadi*, Novira Kusrini, Dewi Kurniati, Wanti Fitrianti, Joshua Parulian \\ Agribusiness Study Program, Faculty of Agriculture, Tanjungpura University \\ Jl. Prof. Dr. H. Hadari Nawawi, Pontianak 78124 \\ * Corresponding author: maswadi@faperta.untan.ac.id
}

\begin{abstract}
Abstrak: Kelapa (Cocos nucifera L.) adalah komoditas perkebunan yang cukup berkembang di Kalimantan Barat. Namun, potensi kelapa yang besar masih terdapat kelemahan dalam struktur agribisnis yang berlaku di Indonesia yaitu keterpaduan (integrasi) yang berhubungan erat dengan ketersediaan kelapa dalam. Penelitian ini bertujuan untuk melihat tingkat kedekatan hubungan pasar regional kelapa dalam dengan pasar regional lain di Kalimantan Barat yang diwakili oleh Kabupaten Bengkayang, mempawah, dan Kabupaten Sambas yang dianalisis mengunakan vector autoregression (VAR) untuk meneliti hubungan jangka panjang. Keterpaduan produksi kelapa dalam Kabupaten Bengkayang, Mempawah, dan Sambas dalam dianalisis menggunakan uji kausalitas Granger. Data yang digunakan adalah data sekunder kuantitatif tahunan selama 14 tahun pada rentang waktu antara 2004 hingga 2017 yang harus stasioner di tingkat first difference. Hasil dari penelitian ini menunjukkan bahwa produksi Kalimantan Barat mengalami sebagian terjadi hubungan kausalitas dua arah dan sebagian hanya satu arah. Produksi Bengkayang memengaruhi Sambas, namun produksi Sambas tidak memengaruhi produksi Bengkayang. Ini menunjukkan terjadi hubungan kausalitas satu arah. Hal ini dapat terjadi karena perbedaan kualitas produksi. Produksi Mempawah dan Bengkayang menunjukkan tidak adanya hubungan kausalitas antara kedua negara. Produksi Mempawah memengaruhi Sambas. Ini menunjukkan terjadi hubungan kausalitas dua arah. Saran dari penelitian ini adalah pemerintah perlu meningkatkan dan menambah kebutuhan fasilitas infrastruktur untuk pelaku pasar dan pelaku pasar perlu mengikuti metode produksi dari media elektronik atau institusi terkait.
\end{abstract}

Kata kunci: integrasi pasar, uji kausalitas Granger, kelapa, vector autoregression (VAR)

\begin{abstract}
Coconut (Cocos nucifera L.) is one of the most developed plantation commodities in West Kalimantan. However, the coconut has a problem with the structure of agribusiness, namely the alignment (integration) that is closely related to the availability of the coconut. This research aims to see the level of proximity of coconut regional market relationship with other regional markets in West Kalimantan represented by Bengkayang Regency, Mempawah, and Sambas district, which analyzed using vector autoregression (VAR) to examine the long-term relationship. The integration of coconut production in Bengkayang, Mempawah, and Sambas districts was analyzed using the Granger causality test. The data used is the annual quantitative secondary data for 14 years in the time range between 2004 and 2017, which must be stationary at the first difference level. This study showed that West Kalimantan's production experienced some two-way causality relationship and some only one way. Production of Bengkayang affects Sambas, but the production of Sambas does not affect the production of Bengkayang. This finding indicates a oneway causality relationship. It is suggested that the government needs to add and improve infrastructure facilities for market players, and market players must follow
\end{abstract}


production method information through electronic media or related institutions (for example, Department of Agriculture).

Keywords: market integration, Granger causality test, coconut, vector autoregression (VAR)

\section{INTRODUCTION}

Indonesia is known as a country that has a strong agricultural base. The agricultural sector can survive and at the same time become a support for the Indonesian economy in the global economic and monetary crisis a few years ago. The contribution of the Indonesian agricultural sector to GDP during the period 2000-2015 continued to decline from year to year, from $15.60 \%$ in 2000 to $11.98 \%$ in 2015 (Marwanti et al., 2017).

Coconut (Cocos nucifera L.) is a tropical plantation commodity that is widely grown in Indonesia, the Philippines, India, Sri Lanka, and several Asia Pacific countries ((Perera et al., 2012). Coconut plays a role in the economic, social, and cultural life of the Indonesian people and state revenue from nonoil and gas commodities (Alouw and Wulandari, 2020; UNDP, 2013).

West Kalimantan is the largest producer of coconut in Kalimantan Island, with the production of 81.123 tons (in 2019) or contributing more than $50 \%$ of coconut production in Kalimantan Island at 134,652 tons (in 2019) (Dirjenbun, 2019).

As one of the market players, the government has a role in creating strategic agricultural product price stabilization. While there are still weaknesses of the agribusiness structure prevailing in Indonesia, integration analysis is critical (Tedjaningsih et al., 2018). Integration that is the focus of the government is the availability of coconut. Supervision of the availability of coconuts is helpful to facilitate the monitoring of price changes. Implementing the price stabilization policy will be more effective in integrated markets than in non-integrated markets (Farid et al., 2014). The impact of these Government interventions can be channeled to other markets to carry out pricing policies effectively. However, This research aims to see the level of proximity of coconut regional market relationship with other regional markets in West Kalimantan represented by Bengkayang Regency, Mempawah, and Sambas district, which analyzed using vector autoregression (VAR) to examine the long-term relationship.

\section{RESEARCH METHOD}

This research was conducted in March 2019. The data of this study are secondary data obtained from various sources (Sugiyono, 2017) and literature including data on coconut production in Bengkayang people's plantations, coconut production in Mempawah, coconut production in Sambas representing coconut production in West Kalimantan Province. The data has also been tested and passed the classic assumption test. The variables used are coconut production in Bengkayang, coconut production in rice fields, coconut production in Sambas.

Data analysis used in this research was the vector autoregression (VAR) model indifference, Impulse Response Analysis to determine the impact of the response of each variable due to shock, and variance decomposition (Fazaria et al., 2016). VAR analysis use E-VIEWS. The model are shown in equation 1.

Stationary test Unit root test data using the ADF test found that stationary data at first difference with a value of Prob $0,000<$ alpha 0.05 (level to 5\%). All variables do not show causality based on the causality test results, so VAR indifference with optimum lag 2 is used.

\section{RESULT AND DISCUSSION}

\section{Analysis of the Position of Coconut in West Kalimantan}

Coconut is one of the competitive products in Southeast Asia (Firmansyah et al., 2017). The use of coconut products traditionally is for

$$
\begin{aligned}
(\times \text { production }) & =\alpha_{1}-\beta_{1} d(\text { bengkayang })_{t-1}-\beta_{2} d\left(\text { bengkayang }_{t-2}+\beta_{3} d\left(\text { mempawah }_{t-1}\right.\right. \\
& +\beta_{4} d(\text { mempawah })_{t-2}+\beta_{5} d(\text { sambas })_{t-1}+\beta_{6} d\left(\text { sambas }_{t-2}\right.
\end{aligned}
$$


fresh consumption, processed into copra or coconut oil. Demand for coconut-derived products is also increasing in desiccated coconut, coir fibers, shell charcoal, and activated charcoal (Sangamithra et al., 2013). However, there is a decreasing tendency for coconut consumption. This is inseparable from the emergence of palm oil as a substitute commodity for coconut (Sianipar, 2009). Coconut production in West Kalimantan (Figure 1).

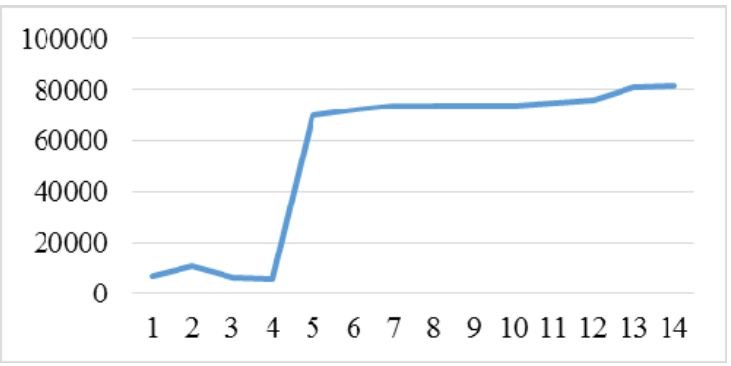

Figure 1. Coconut production in West Kalimantan in 2004-2017

Figure 1 shows the fluctuating trend in coconut production in West Kalimantan. Therefore, stakeholders need to pay attention to the continuity of production and prevent low quality through superior seeds (Luengwilai et al., 2014).

One way to safeguard this is to use tissue culture seeds and seed breeding to lower the price of seeds and reduce fertilizer doses to reduce production costs. In addition, farmers also need to be educated to use superior seeds (Rini and Sujianto, 2013).

\section{VAR Analysis Model}

VAR model is used to predict production data based on the movement of production itself in the past (Lag production) plus information about the movement of predictor variables in the past (lag variable predictor). Based on the vector autoregression estimates, it is known that the endogenous variables in the equation above can explain the diversity of food ingredients as much as $95.4 \%$ (R-squared). The formed equation model is shown in equation 2 .

Bengkayang coconut production is significantly affected by Bengkayang production, Mempawah coconut production, and coconut production in Sambas (equation 2). This finding shows that the influence of lag 1 value of Bengkayang production is significant on rice fields and Sambas production. In contrast, the effect of lag 1 of Bengkayang production is a small contribution to the Bengkayang movement itself.

The lag 2 value of Bengkayang production is significant to Mempawah production and Sambas production. In contrast, the effect of lag 2 from Bengkayang production has a small contribution to the movement of Bengkayang itself.

The equation above also shows that changes in production in Bengkayang one year ago increased by one ton, it will cause changes in production in Bengkayang itself decreased by 0.50 percent, and it also applies if changes in production in Bengkayang two years ago by one ton, it will cause changes in production in Bengkayang itself decreased 0.26 percent.

Changes in production at Mempawah one year ago increased by one ton will cause changes in production at Bengkayang to increase by 0.02 percent. It also applies if production changes at Mempawah two years ago by one ton, it will cause changes in production at Bengkayang increased 0.01 percent. In addition, changes in production in Sambas one year ago increased by one ton. It will cause changes in production in Bengkayang to increase by 0.0706 percent and changes in production in Sambas two years ago by one ton will cause changes in production in Bengkayang increased 0.05 percent. It is shown in equation 3.

$$
\begin{aligned}
d(\text { bengkayang production })= & 18.80-0.50 d(\text { bengkayang })_{t-1}-0,26 d(\text { bengkayang })_{t-2} \\
& +0.02 d(\text { mempawah })_{t-1}+0.01 d(\text { mempawah })_{t-2}+0.07 d(\text { sambas })_{t-1} \\
& +0.05 d(\text { sambas })_{t-2}
\end{aligned}
$$

$d$ (mempawah production)

$$
\begin{aligned}
& =1549.26-22.99 d(\text { bengkayang })_{t-1}+14.20 d(\text { bengkayang })_{t-2}+0.39 d(\text { mempawah })_{t-1} \\
& +0.52 d(\text { mempawah })_{t-2}+2.59 d(\text { sambas })_{t 1}+3.23 d\left(\text { sambas }_{t 2}\right.
\end{aligned}
$$


d(sambas production)

$$
\begin{aligned}
& =-214.00+1.82 d(\text { bengkayang })_{t-1}-0.46 d\left(\text { bengkayang }_{t-2}-0.0108 d\left(\text { mempawah }_{t-1}\right.\right. \\
& -0.029 d(\text { mempawah })_{t-2}-0.01 d(\text { sambas })_{t-1}-0.22 d(\text { sambas })_{t-2}
\end{aligned}
$$

Coconut production in Mempawah is significantly affected by Bengkayang production, Mempawah production, and coconut production in Sambas (equation 3). The data also shows the influence of lag 1 value from Mempawah production significantly to the production of mempawah and Sambas, while the effect of lag 1 from Mempawah production has a small contribution to the Bengkayang movement. In the lag 2 value of Mempawah production is significant to the production of Mempawah, Bengkayang, and Sambas. The above equation also shows that if changes in production at Mempawah one year ago increased by one ton, it would change production at Bengkayang to decrease by 22.99 percent and also applies if production changes at Bengkayang itself two years ago by one ton, would cause changes in production at Bengkayang itself increased by 14.20 percent.

Changes in production at Mempawah itself one year ago increased by one ton will cause changes in production at Mempawah increased by 0.39 percent. It also applies if changes in production at Mempawah two years ago by one ton will cause changes in production at Mempawah increased 0.52 percent.

In addition, changing production in Sambas one year ago increased by one ton, will change production in Mempawah itself to increase by 2.5872 percent and a change in production in Sambas two years ago by one ton, will change production in Mempawah itself to increase by 3.2261 percent. It is shown in equation 4.

Coconut production in Mempawah is significantly affected by Bengkayang production, Mempawah coconut production, and coconut production in Sambas (equation 4). The data shows that the influence of lag 1 from Sambas production is significant to Bengkayang production. In contrast, the effect of lag 1 from Sambas production is a small contribution to Mempawah and Sambas' movement.

Meanwhile, the lag 2 value of Sambas production is insignificant to Mempawah, Bengkayang, and Sambas production. The above equation also shows that if a change in production at Bengkayang last year increased by one ton, it would cause a change in production at Sambas to increase by 1.82 percent and also applies if a change in production at Bengkayang two years ago by one ton, would cause a change in production at Sambas to decrease 0.46 percent.

A change in production at Mempawah one year ago increased by one ton and will cause changes in production in Sambas itself decreased by 0.01 percent and also applies if changes in production at Mempawah two years ago by one ton will cause changes in production at Sambas to decrease 0.03 percent.

In addition, changes in production in Sambas one year ago increased by one ton, which will cause changes in production in Sambas to decrease by 0.014 percent, and changes in production in Sambas two years ago by one ton will cause changes in production in Sambas to decrease by 0.22 percent.

\section{Forecasting of Coconut Production}

Vector Auto Regression (VAR) can be used to forecast coconut production in the next 10 years (Figure 2).

Coconut production in each region shows a declining trend because farming management is still traditional, the age of relatively unproductive workers, farmers' insights are limited, especially education (Guo et al., 2015; Oduro-ofori et al., 2014).

Other causes are the direct involvement of the government, industry, and the consumer community in the field, which is still very lacking, productivity is still low, cultivation with random seeds, and does not provide special treatment such as fertilization and root regulation (Patty, 2011).

Efforts that can be made to increase production are based on appropriate technology-based agriculture such as weed and fertilization control technology (Kemala, 2015) and making systems and businesses based on agribusiness that are competitive, sustainable, democratic, and decentralized (UNDP, 2013). A competitive agribusiness system can enhance the ability to manage farmers and support 
government policies, counseling, banking, and the National Logistics Agency (Sinaini et al., 2017).

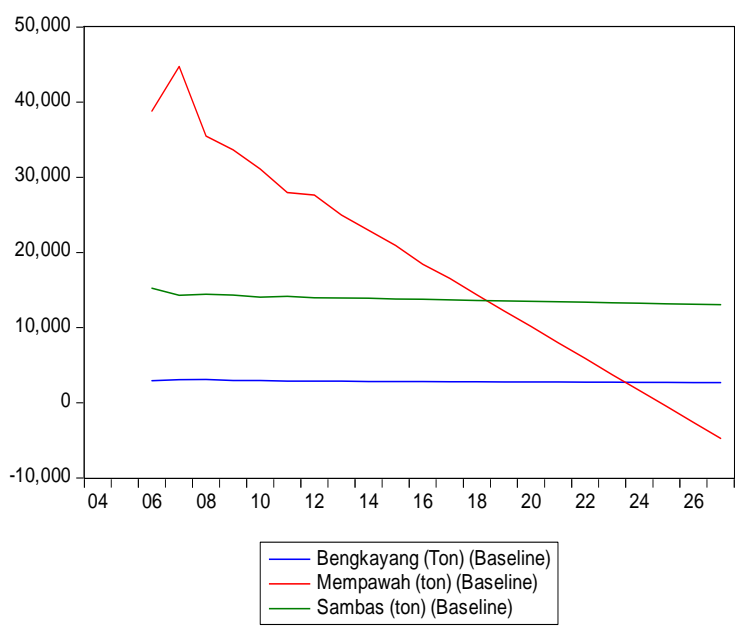

Figure 2. Forecasting of coconut production in the next 10 years

Another way is the rejuvenation of coconut. Rejuvenation of coconut can increase coconut farmers' income (Muslim and Darwis, 2018).

\section{Impulse Response Analysis}

The Impulse Response Function (IRF) traces the contemporary effect of a shock deviation standard from innovation to the values of current endogenous variables or future values.

The shock from endogenous variables directly affects the variable itself (Subekti and Carolina, 2011). Figure 2 shows the impact of the response of a variable due to the shock of other variables up to ten periods after the shock. The response of a variable due to a shock will gradually disappear (close to 0 ) and return to the previous balance and will not leave a permanent impact on the variable.

The pattern indicates that the VAR specification involves variable coconut production in Bengkayang, coconut production in Sambas, and Mempawah is correct.

Figure 2 also shows that the impact of the response received by Bengkayang production due to Bengkayang production shocks for 10 years is convergence which is indicated by a graph that goes to zero. The graph shows that at the beginning of the period/month, the shock on the Bengkayang variable production caused price fluctuation, which was very fluctuating until the 7th period.
Response to Cholesky One S.D. Innovations \pm 2 S.E.

Response of D(BENGKAYANG_TON_) to D(BENGKAYANG_TON_)

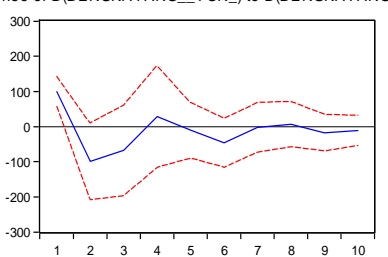

Response of D(MEMPAWAH_TON_) to D(BENGKAYANG_TON_)

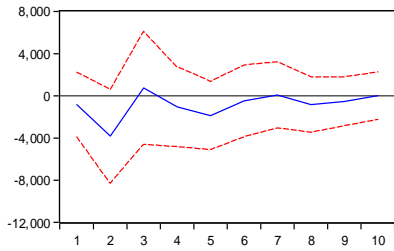

Response of D(SAMBAS_TON_) to D(BENGKAYANG_TON $)$

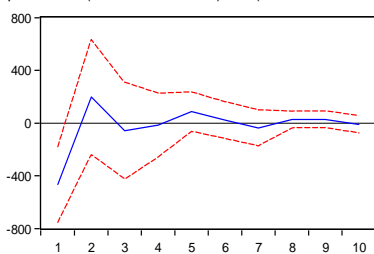

ponse of D(BENGKAYANG TON ) to D(MEMPAWAH TON

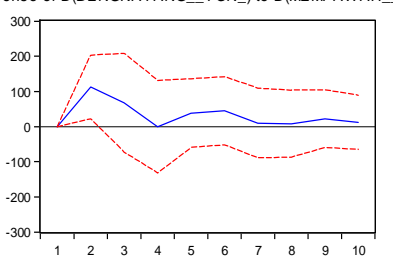

Response of D(MEMPAWAH_TON_) to D(MEMPAWAH_TON_)

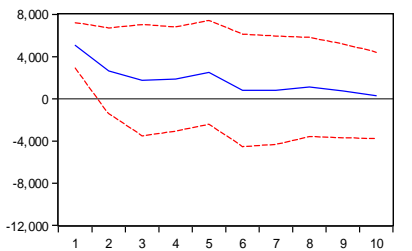

Response of D(SAMBAS_TON_) to D(MEMPAWAH_TON_)

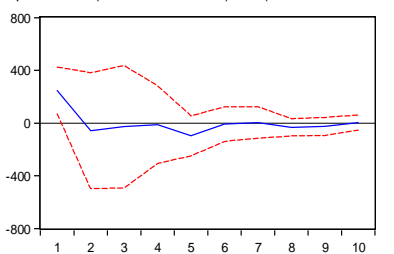

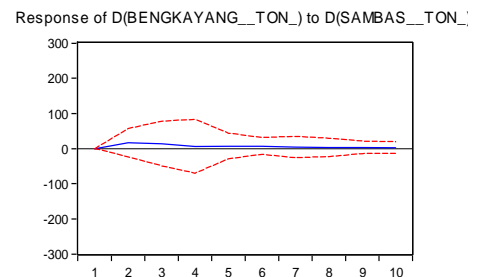

Response of D(MEMPAWAH_TON_) to D(SAMBAS_TON_)

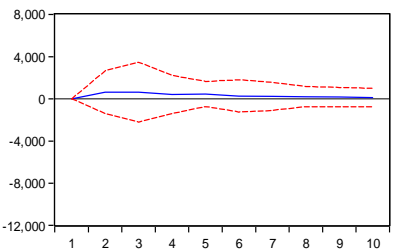

Response of D(SAMBAS_TON_) to D(SAMBAS_TON_)

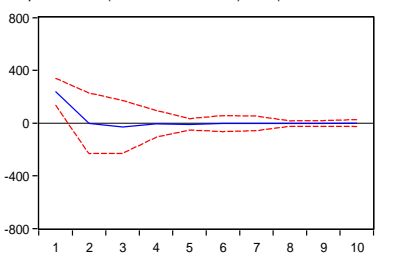

Figure 3. Impulse response analysis result 
After that, the graph shows the heading to the point of balance or towards zero. The same pattern also applies to 15 other response graphs that are generally stable. Positive fluctuating patterns are shown in the Bengkayang production graph against Mempawah production and Mempawah production against Mempawah production. The variable production of Sambas production in the graph above shows a graph that tends to be linear and stable on a line close to zero. Production stability will be good if the shock does not produce temporary changes and the variation is relatively small.

\section{Analysis Forecast Error Decomposition Variance (FEDV)}

The first column explains that the variance of decomposition or an important source of variation in Bengkayang production is shocking from Bengkayang production itself. In contrast, due to shocks from other variables, namely Mempawah production is quite influential, but the production of Sambas is relatively small.

Variations of coconut production in Bengkayang in the first period of shocks were contributed $100 \%$ by coconut production in Bengkayang itself. Meanwhile, 61 percent of shocks in the second period were contributed by Bengkayang, 38 percent by Mempawah, and the rest by Sambas, which had relatively little effect. A different pattern occurred in the third to tenth periods, namely shocks in coconut production in Bengkayang contributed by 5658 percent.

The second column explains that the variance of decomposition or an important source of variation in Mempawah production is shocking from Mempawah production itself. In contrast, due to shocks from other variables, namely Bengkayang production is quite influential and Sambas production is relatively small. Variation of coconut production in Mempawah in the first period of shocks was contributed by 97.3 percent of coconut production in Mempawah itself and Bengkayang 2.7 percent.

In the second to tenth period, the percentage of stable shocks was contributed by Mempawah by 67.3 percent, 31 percent by Bengkayang, the rest by Sambas, which was 1.7 percent. This is relatively stable. Bengkayang influences shocks, the percentage of shocks is 28.17 percent per period, Mempawah averages 70.3 percent, and the rest is contributed by Sambas, which is an average of 1.53 percent.

The third column explains that the variance of decomposition or an important source of variation in Sambas production is shocking from Bengkayang production. In contrast, production is relatively similar due to shocks from other variables, namely Mempawah and Sambas. This finding shows that Bengkayang largely determines the Sambas production shock.
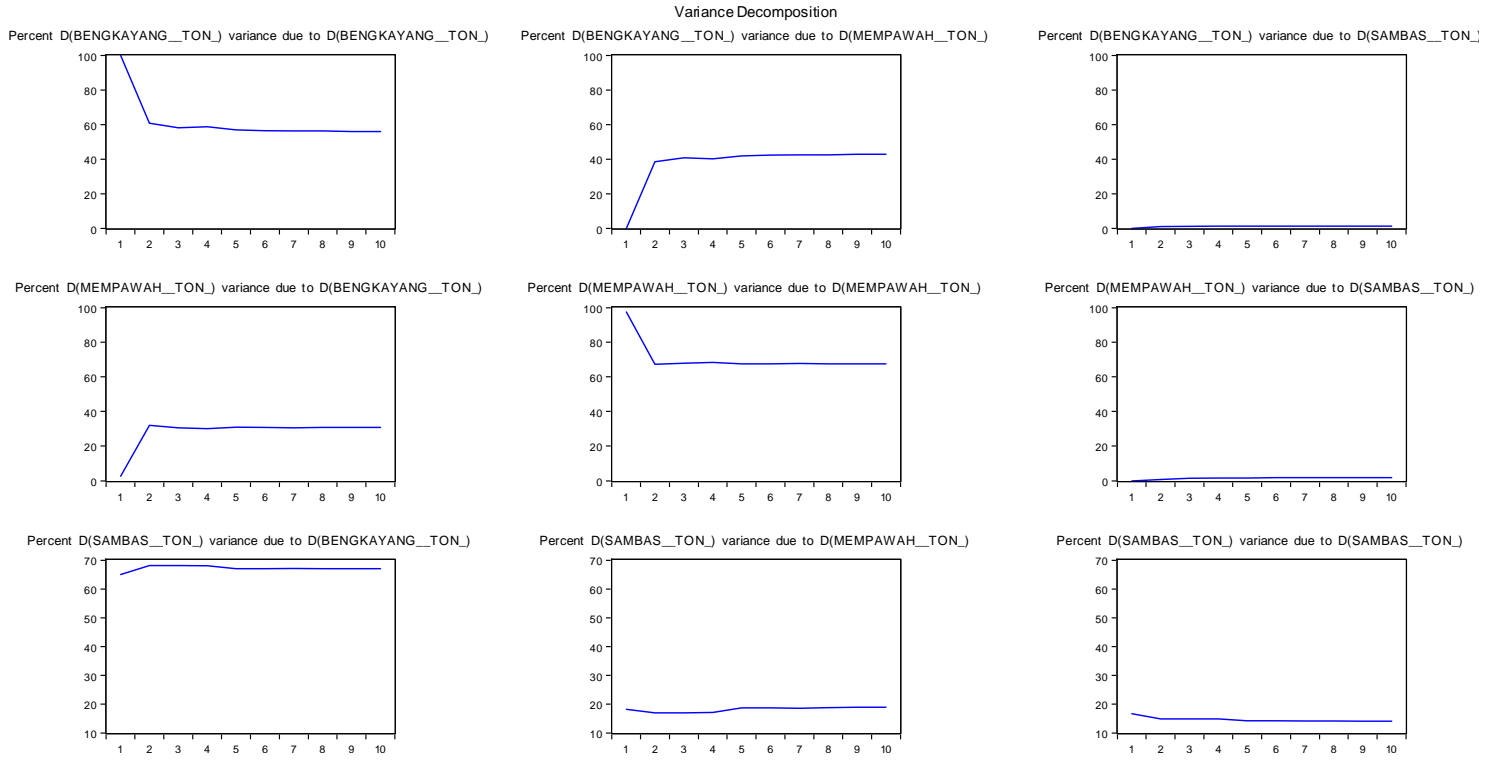

Figure 4. FEDV analysis results 
The first period of shocks showed variations in coconut production in Sambas contributed by coconut production in Bengkayang at 65 percent, in Mempawah 18 percent and in Sambas 17 percent. Meanwhile, in the second to tenth period, the percentage of stable shocks was contributed by an average of 67.2 percent, an average of 17.6 percent by Bengkayang, the rest by Sambas, which was 15.2 percent. The third column shows that Bengkayang strongly influences sambas.

\section{Granger Causality Analysis}

Granger causality test was conducted to determine the causality relationship between Bengkayang, Sambas, and Mempawah production. Based on testing with a null hypothesis on the whole line, Bengkayang, Sambas, and Mempawah do not affect each other. By using the criteria with a level of $5 \%$, it can be seen that some hypotheses are rejected so that there is a partial two-way causality relationship and some only one direction.

Bengkayang production affects Sambas, which is seen from the probability value (0.5) greater than alpha $5 \%$, but Sambas production does not affect Bengkayang production, resulting in a one-way causality relationship due to differences in production quality. Mempawah and Bengkayang Production show that there is no causal relationship between the two countries. Mempawah production affects Sambas as seen from a probability value $(0.45)$ greater than alpha $5 \%$ and vice versa, resulting in a two-way causality relationship.

\section{CONCLUSION}

The results of the VAR analysis of the three equations are significant. The results of Impulse Response show the impact of the response of another variable with ten periods after the shock. It appears that the response of a variable due to a shock will gradually disappear and return to the next balance and will not leave a permanent impact on that variable. It is suggested that the government needs to add and improve transportation facilities for market players. In addition, market players must follow production method information through electronic media or related institutions (for example, Department of Agriculture).

\section{REFERENCE}

Alouw, J. C., \& Wulandari, S. (2020). Present status and outlook of coconut development in Indonesia. IOP Conference Series: Earth and Environmental Science, 418(1). https://doi.org/10.1088/17551315/418/1/012035.

Dirjenbun. (2019). Statistik perkebunan Indonesia 2018-2020. Buku Statistik Perkebunan Indonesia, 1-82. https://drive.google.com/file/d/1FVxpBN ihnuB3ayAALBi-FtsBShIUxMTD/view.

Farid, M., Wicaksena, B., Nuryati, Y., Prabowo, D. W., Yulianti, A., \& Haryana, A. (2014). Analisis Kebijakan Harga pada Komoditas Pertanian. 56. http://bppp.kemendag.go.id/media_conte nt/2017/08/Analisis_Kebijakan_Harga_P ada_Komoditas_Pertanian.pdf.

Fazaria, D. A., Hakim, D. B., \& Sahara, S. (2016). Analisis integrasi harga lada di pasar domestik dan internasional. Buletin Ilmiah Litbang Perdagangan, 10(2), 225-242. https://doi.org/10.30908/bilp. v10i2.55.

Firmansyah, F., Widodo, W., Karsinah, K., \& Oktavilia, S. (2017). Export performance and competitiveness of Indonesian food commodities. Jejak, 10(2), 289-301.http s://doi.org/10.15294/jejak.v10i2.11294.

Guo, G., Wen, Q., \& Zhu, J. (2015). The impact of aging agricultural labor population on farmland output: from the perspective of farmer preferences. Mathematical Problems in Engineering, 2015, 1-7.https://doi.org/10.1155/2015/7 30618.

Kemala, N. (2015). Kajian pendapatan dan kontribusi usahatani kelapa (Cocos nucifera) terhadap pendapatan keluarga petani di Kabupaten Tanjung Jabung Barat, Provinsi Jambi. Jurnal Ilmiah Universitas Batanghari Jambi, 15(3), 125-132. 
Luengwilai, K., Beckles, D. M., Pluemjit, O., \& Siriphanich, J. (2014). Postharvest quality and storage life of "Makapuno" coconut (Cocos nucifera L.). Scientia Horticulturae, 175(August), 105-110. https://doi.org/10.1016/j.scienta.2014.06. 005.

Marwanti, S., \& Irianto, Heru, S. (2017). The effects of export, import, and investment on the growth of the Indonesian agricultural sector. Jurnal Agro Ekonomi, 35(1), 49-65.

Muslim, C., \& Darwis, V. (2018). Peningkatkan kesejahteraan petani melalui inovasi teknologi produk turunan kelapa dalam di Sulawesi Barat. SEPA: Jurnal Sosial Ekonomi Pertanian Dan Agribisnis, 14(1), 18.https://doi.org/10. 20961/sepa.v14i1.21038.

Oduro-ofori, E., Aboagye Anokye, P., \& Acquaye, N. E. A. (2014). Effects of education on the agricultural productivity of farmers in Offinso Municipality. International Journal of Development Research, 4(9), 1951-1960.

Patty, Z. (2011). Analisis produktivitas dan nilai tambah kelapa rakyat (Studi kasus di 3 kecamatan di Kabupaten Halmahera Utara). Jurnal Agroforestri, 6(2), 12. https://webcache.googleusercontent.com/ search?q=cache:HaVY0g5MccoJ:https:// jurnalee.files.wordpress.com/2012/12/an alisis-produktivitas-dan-nilai-tambahkelaparakyat.pdf $+\& \mathrm{~cd}=2 \& \mathrm{hl}=\mathrm{id} \& \mathrm{ct}=\mathrm{cln}$ $k \& c l i e n t=$ firefox-b.

Perera, L., Meegahakumbura, M., Wijesekara, H., Fernando, W., \& Dickinson, M. (2012). A Phytoplasma is associated with the Weligama coconut leaf wilt disease in Sri Lanka. Journal of Plant Pathology, 94(1), 205-209.

Rini, E., \& Sujianto. (2013). Perceptive of farmers and feasibility on the development of patchouli tissue culture seeds. Bul. Littro, 24(1), 49-56.http://bal ittro.litbang.deptan.go.id/ind/images/publ ikasi/bul.vol.24.no.1/8-Rini-Tanggap

Petani-Kultur Jaringan.pdf.

Sangamithra, A., Swamy, G. J., Sorna, P. R., Chandrasekar, V., Sasikala, S., \& Hasker, E. (2013). Coconut value added products: An extensive review on value added products. Indian Food Industry Magazine, 32(6), 1-9.

Sianipar, T. M. (2009). Analisis respons penawaran kelapa di Indonesia pada periode 1971-2006 [Skripsi]. IPB, Bogor.

Sinaini, L., Rianse, U., \& La Ola, T. (2017). Role study of farmer groups and the combination of maize farmer groups in Muna District. IOSR Journal of Business and Management, 19(11), 76-83.https:// doi.org/10.9790/487X-1911067683.

Subekti, N. A., \& Carolina, R. A. (2011). Pengaruh kebijakan tarif impor gula terhadap integrasi pasar gula domestik dan dunia. Buletin Ilmiah Litbang Perdagangan, 5(1), 84-103.http://jurnal. kemendag.go.id/index.php/bilp/article/vi ew/121/81.

Sugiyono. (2017). Statistika Untuk Penelitian. Alfabeta.

Tedjaningsih, T., Suyudi, S., \& Nuryaman, H. (2018). Peran kelembagaan dalam pengembangan agribisnis mendong. MIMBAR AGRIBISNIS: Jurnal Pemikiran Masyarakat Ilmiah Berwawasan Agribisnis, 4(2), 210. https://doi.org/10.25157/ma.v4i2.898.

UNDP. (2013). Kajian Kelapa dengan Pendekatan Rantai Nilai dan Iklim Usaha di Kabupaten Sarmi. BBC News, ILO PCdP, 60.http://news.bbc.co.uk/1/shared /spl/hi/uk/05/born_abroad/countries/html /south_africa.stm. 